\title{
Grazing on green algae by the periwinkle Littorina littorea in the Wadden Sea
}

\author{
U. Wilhelmsen \& K. Reise \\ Biologische Anstalt Helgoland, Wattenmeerstation Sylt; D-25992 List, \\ Federal Republic of Germany
}

\begin{abstract}
On sedimentary tidal flats in the Wadden Sea near the Island of Sylt, the periwinkle Littorina littorea occurred preferentially on clusters and beds of mussels and on shell beds (100 to $350 \mathrm{~m}^{-2}$ ), achieved moderate densities on green algal patches or mats $\left(20\right.$ to $\left.50 \mathrm{~m}^{-2}\right)$, and remained rare on bare sediments $\left(<5 \mathrm{~m}^{-2}\right)$. Green algae covering $>10 \%$ of sediment surface appeared in summer on approximately one third of the tidal zone, mainly in the upper and sheltered parts and almost never on mussel and shell beds. In feeding experiments, L. Littorea ingested more of the dominant alga, Enteromorpha, than of Ulva, irrespective of whether or not algae were fresh or decaying. The tough thalli of Chaetomorpha were hardly consumed. Snails feeding on Enteromorpha produced fecal pellets from which new growth of Enteromorpha started. In the absence of periwinkles, Enteromorpha developed on mussels and the attached fucoids. Experimentally increased snail densities on sediments prevented green algal development, but the snails were unable to graze down established algal mats. It is concluded that natural densities of $L$. littorea hardly affect the ephemeral mass development of green algae on sediments. However, where the snails occur at high densities, i.e. on mussel beds, green algal development may be prevented.
\end{abstract}

\section{INTRODUCTION}

Enhanced eutrophication appears to have led to an extensive development of green algae (Chlorophyceae) on the tidal flats of the Wadden Sea during summer (Reise, 1983; Reise \& Siebert, 1994). The dominant genera are Enteromorpha, Chaetomorpha, Cladophora and Ulva. Sediments completely covered by algae turn anoxic and this affects the infauna (Soulsby et al., 1982; Hull, 1987). However, mats also provide food for herbivores and an abundant supply of detritus for deposit feeders (Price \& Hylleberg, 1982; Levinton \& McCartney, 1991). Ducks and geese (Anas penelope, Branta bernicla) are able to use algal mats as a food source (Nicholls et al., 1981). Epibenthic macrofauna like amphipods (Brenner et al., 1976; Hylleberg \& Henriksen, 1980), isopods (Nicotri, 1980) and other Crustacea (Warwick et al., 1982) also ingest green algae. Nereid polychaetes anchor Enteromorpha and Ulva thalli at their tubes and ingest pieces of plant tissue (Woodin, 1977). The mudsnail Hydrobia ulvae occurs in high densities in the mats, but it is not known whether these snails consume green algal tissue or mainly the microflora (i.e. diatoms) covering the surface of the macroalgae (Jensen \& Siegismund, 1980).

The periwinkle Littorina littorea is predominantly herbivorous and prefers ephemeral green algae like Enteromorpha and Ulva to all other macroalgae (Watson \& Norton, 
1985a). The versatility of their taenioglossan radula enables feeding on macroscopic as well as microscopic stages of algal development (Norton et al., 1990). The sporadic and patchy distribution of Enteromorpha and Ulva may render these algae too unpredictable as a food source to sustain large populations of specialist grazers (Cates \& Orians, 1975; Littler \& Littler, 1980). L. littorea, however, is a general herbivore, and efficiently uses the periodic availability of such valuable food sources (Lubchenco, 1978). Experimental exclusion of $L$. littorea on rocky shores showed that periwinkles at high densities are able to prevent the establishment of green algae (Lein, 1980; Lubchenco, 1983; Petraitis, 1983).

The influence of this herbivorous snail on the development of green algae on sedimentary tidal flats in the Wadden Sea is not known, but may be substantial - at least in habitats where snail densities are high, e.g. in beds of seagrass, shells or mussels (Wohlenberg, 1937; Linke, 1939). In this investigation, laboratory and field studies were performed to explore the importance of Littorina littorea for the development of green algae in different habitats in the Wadden Sea.

\section{MATERIALS AND METHODS}

\section{Study site}

Investigations were carried out in Königshafen, a shallow, sheltered Wadden Sea bay near the Island of Sylt (North Sea). Hydrography and sediments have been described by Austen (1990), distribution of macroalgae by Nienburg (1927) and Kornmann (1952). Extensive mats of green algae have been present on the tidal flats for about 10 years (Reise, 1983; Reise et al., 1989).

\section{Distribution of periwinkles and green algae}

Snail densities and the occurrence of macroscopic green algae were mapped twice, in April and July 1992, in the southern part of Königshafen. Percentage cover of green macroalgae on tidal flats was estimated visually for areas of $50 \times 50 \mathrm{~m}$. Meese \& Tomich (1992) tested several percent cover estimation methods, i.e. visual estimation, evenly spaced dots, random dòts, stratified random dots and electronic digitizing of photographic images for repeatability and robustness against observer bias. Digitizing of photographic images was found to be the most precise - but costly. The estimates derived from the other techniques were not significantiy different from each other. Therefore, time-saving visual estimation was used for this investigation.

Snail densities were determined with an aluminium frame $\left(0.25 \mathrm{~m}^{2}\right)$, divided into smaller areas $\left(0.01 \mathrm{~m}^{2}\right)$ to facilitate counting. The frame was thrown haphazardly several metres for sampling. Seven replicate counts of snail densities were made every $50 \mathrm{~m}$. Bare sediment flats, patches or mats of green algae, beds of seagrass and shells, stones, as well as clusters and banks of mussels (Mytilus edulis) were sampled separately with 7 replicates each, because they provide different habitats for periwinkles on tidal flats (Wohlenberg, 1937; Linke, 1939). 


\section{Ingestion rates}

The ingestion of green algae by Littorina littorea was measured in the laboratory according to a modified method of Shacklock \& Doyle (1983). Snails with a medium shell height $(19 \pm 1 \mathrm{~mm}$, wet weight $2.15 \pm 0.78 \mathrm{~g})$ were sampled and placed in large Petri dishes, which were filled with sterile seawater, covered with fine meshed gauze and incubated at a constant temperature $\left(15^{\circ} \mathrm{C}\right)$ and photoperiod $(16 \mathrm{~h}$ light). After a $48 \mathrm{~h}$ starvation period they were fed with a defined amount (wet weight) of fragmented green algae. Each experiment was run with 10 replicates over 10 days. Water and food were changed every day. The remaining algae were weighed to determine the loss due to ingestion per day. Calculations were based on wet weight of snails and algae since feeding of the snails cannot be done with dried algae. The number of fecal pellets produced was counted every morning with a binocular and examined under a microscope. Ten replicates of algae without grazers served as controls. The ingestion of Enteromorpha, Ulva and Chaetomorpha was compared. Fresh as well as decaying thalli were used to test the influence of algal condition on the ingestion rates.

\section{Caging}

Caging experiments were carried out in a sheltered part of the upper intertidal zone. Cylindrical cages made of wire-mesh $(6.3 \times 6.3 \mathrm{~mm})$ with $54 \mathrm{~cm}$ diameter and $25 \mathrm{~cm}$ height were anchored in the sediment. For each experiment 7 cages and 7 control cages were installed, 1 to $3 \mathrm{~m}$ apart. Littorina littorea was included and excluded in different sets of experiments.

Inclusion experiments. To test the potential influence of grazing on sediment flats, densities of periwinkles were increased in a sandy area with attached strands of Enteromorpha covering approximately $9 \%$ of the sediment surface. Natural density at this site was $<1$ snail per $\mathrm{m}^{2}$ in June 1992. A random choice among strands of green algae was taken to install the cages.

(a) June 4 th to 20 th: Each cage included 50 periwinkles corresponding to densities occurring in mussel beds $\left(200 \mathrm{~m}^{-2}\right)$. Control cages were installed containing no snails.

(b) June 20th to July 5th: To test the effect of grazing on established algal mats, 50 snails were added to each of the control cages of (a) where the algal cover had increased.

The cover of Enteromorpha in the cages was estimated and photographed every day. Pictures were analysed with a screen to determine percent cover of green algae on the sediment. To estimate biomass corresponding to the algal cover in the cages, samples were taken on neighbouring sediment areas with comparable algal cover. Wet weight of Enteromorpha was determined.

Exclusion experiments. May 5th to August 8th: 14 cages were installed on a mud flat covered with clusters of mussels. Each cage contained a cluster with a diameter of $40 \mathrm{~cm}$, which was chosen haphazardly. The periwinkles on mussels or fucoids were counted and excluded from 7 cages. Control cages contained natural snail densities. After 2.5 months, samples of mussels and fucoids were examined under a binocular microscope for the occurrence of green algal germlings. 
Survival of green algae through periwinkle digestive system

Fecal pellets from Littorina littorea were collected and incubated in culture medium to test the ability of green algae to survive digestion. Ten snails each from two green algal mats and a sediment flat were collected and carefully rinsed in sterile seawater to remove algal remains from the shell surface. After $24 \mathrm{~h}$ the produced pellets were transferred to Petri dishes filled with culture medium and incubated at constant temperature $\left(15^{\circ} \mathrm{C}\right)$ and photoperiod (16 h light). Fecal pellets from ingestion experiments in the laboratory were treated in the same way. After 3 weeks fecal pellets were investigated for germlings of green algae.

Results were calculated as mean values with standard deviation $(x \pm y)$. Data of ingestion rates were analysed by a two-factor analysis of variance (ANOVA) with algal species ( 3 levels) and freshness ( 2 levels) as factors, followed by Tukey's HSD multiple comparison test.

\section{RESULTS}

Distribution of periwinkles and green algae

The abundance of Littorina littorea $(>5 \mathrm{~mm})$ on the tidal flats of Königshafen differed between habitats (Fig. 1). Highest densities (100 to $350 \mathrm{~m}^{-2}$ ) occurred on hard

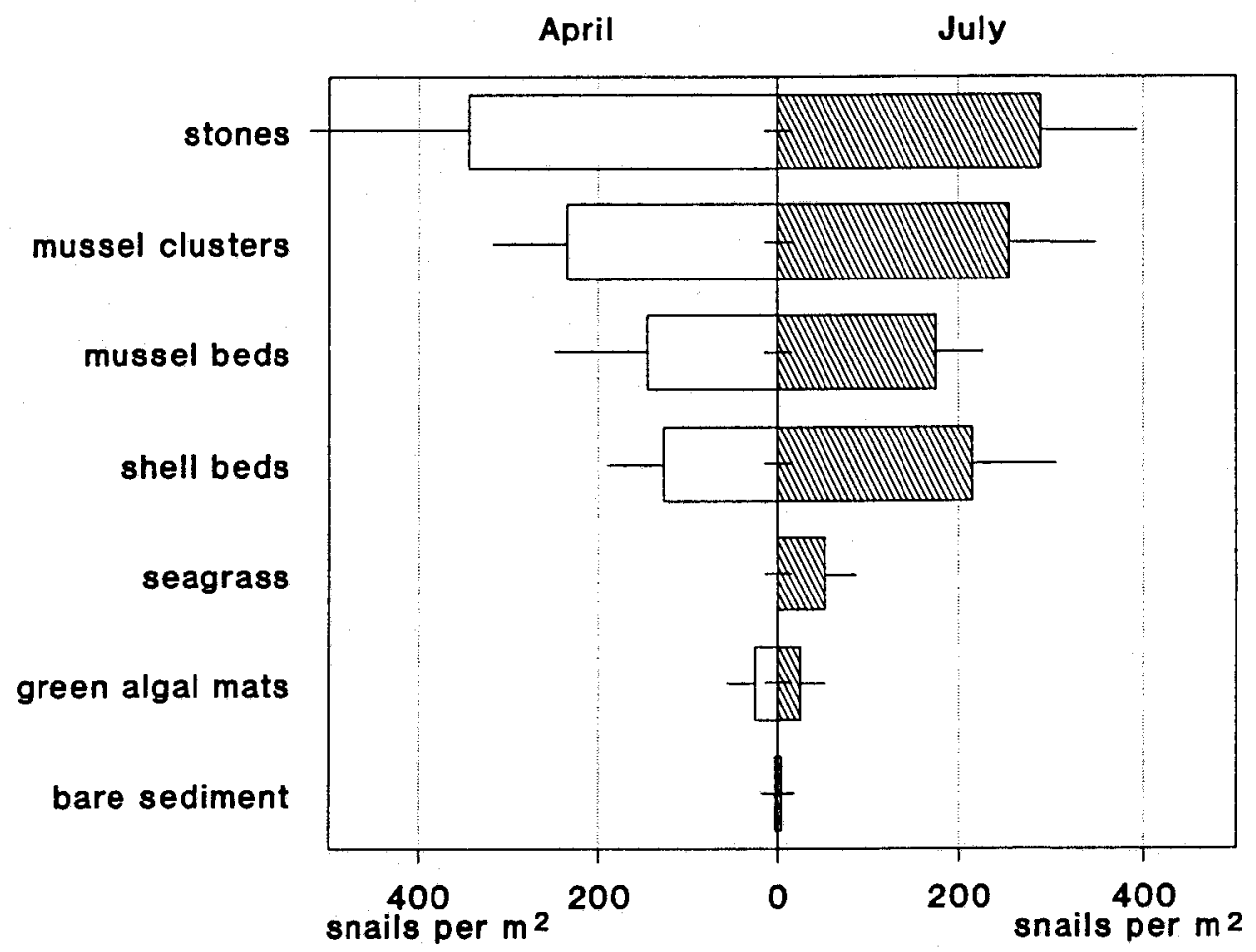

Fig. 1. Abundance of Littorina littorea in different habitats on the tidal flats of Königshafen (mean values and standard deviation with $n \geq 21$ ). Seagrass was absent in April 
substrata (stones, shell beds, aggregates of mussels). Moderate densities (20 to $50 \mathrm{~m}^{-2}$ ) were found on macrophytes (seagrass beds, green algal patches or mats). Hardly any snails were encountered on bare sediments $\left(<5 \mathrm{~m}^{-2}\right)$. Even on some rather small patches of Enteromorpha (app. $2 \mathrm{~m}^{-2}$ ), snail densities were higher (12 to $48 \mathrm{~m}^{-2}$ ) than on the surrounding sediments $\left(0\right.$ to $\left.3 \mathrm{~m}^{-2}\right)$. Green algae occurred on approximately one third of the tidal zone of Königshafen in July. Up to a $100 \%$ cover developed in two sheltered bays, where drifting green algae accumulated. Enteromorpha dominated, but also large amounts of Ulva, Chaetomorpha and Cladophora were present. Mussel and shell beds remained free from attached green algae.

\section{Ingestion rates}

In the feeding experiments, Littorina littorea consumed Enteromorpha more than Ulva. Chaetomorpha was hardly ingested - even after a few days of starvation (Fig. 2). Data from determination of algal wet weight were analysed by a two-factor ANOVA. Significant differences among algal species were found $(p<0.001)$, but not between fresh and decaying algae $(p=0.154)$, although the latter were covered with white sulfur bacteria and had a strong smell of sulfide. Since a significant species $\times$ freshness interaction occurred $(p=0.035)$, two following one-factor ANOVA were performed, separating fresh from decaying algae. Differences between the mean of all three algal species were highly significant (Tukey's test, $\mathrm{p}<0.001$ ). Generally, the same results were obtained by determination of pellet production. Significant differences only occurred between species (two-factor ANOVA, $p<0.001$ ), not between fresh and decaying algae $(\mathrm{p}=0.271)$. The means of all three species differed significantly (Tukey's test, $p<0.001$ ). Wet weight of the ungrazed controls did not change during the $24 \mathrm{~h}$ periods.

\section{Inclusion experiments}

Fifty littorinids per cage were able to decimate a green algal cover of $9 \pm 3 \%(n=7)$ within one day to $2 \pm 3 \%$ cover. After two days, no Enteromorpha was left (Fig. 3). One cage was enveloped with fine-meshed gauze to capture drifting filaments of Enteromorpha. Since no loose thalli were encountered in the net, it is assumed that the snails ingested entire algae, and did not simply detach them from the sediment. Samples of Enteromorpha from areas with a comparable algal cover showed that $10 \%$ cover of the sediment surface corresponds to $7 \mathrm{~g}$ algal wet weight. This was present in the cages at the beginning of the experiment. Therefore, each snail ingested approximately $110 \mathrm{mg}$ Enteromorpha biomass daily. Ingestion rates for Enteromorpha measured in the laboratory were similar $(127 \pm 33 \mathrm{mg}, \mathrm{n}=10)$. In the control cages, Enteromorpha strands grew rapidly. After 16 days, more than $50 \%$ of the sediment surface was covered with green algae. At that time, 50 snails were added to the controls. These snails were not able to graze down the algal biomass. After two weeks, algal cover was still at $50 \%$ in these cages, although snails were observed to feed on the algae just as they did in the first phase of the experiment. 

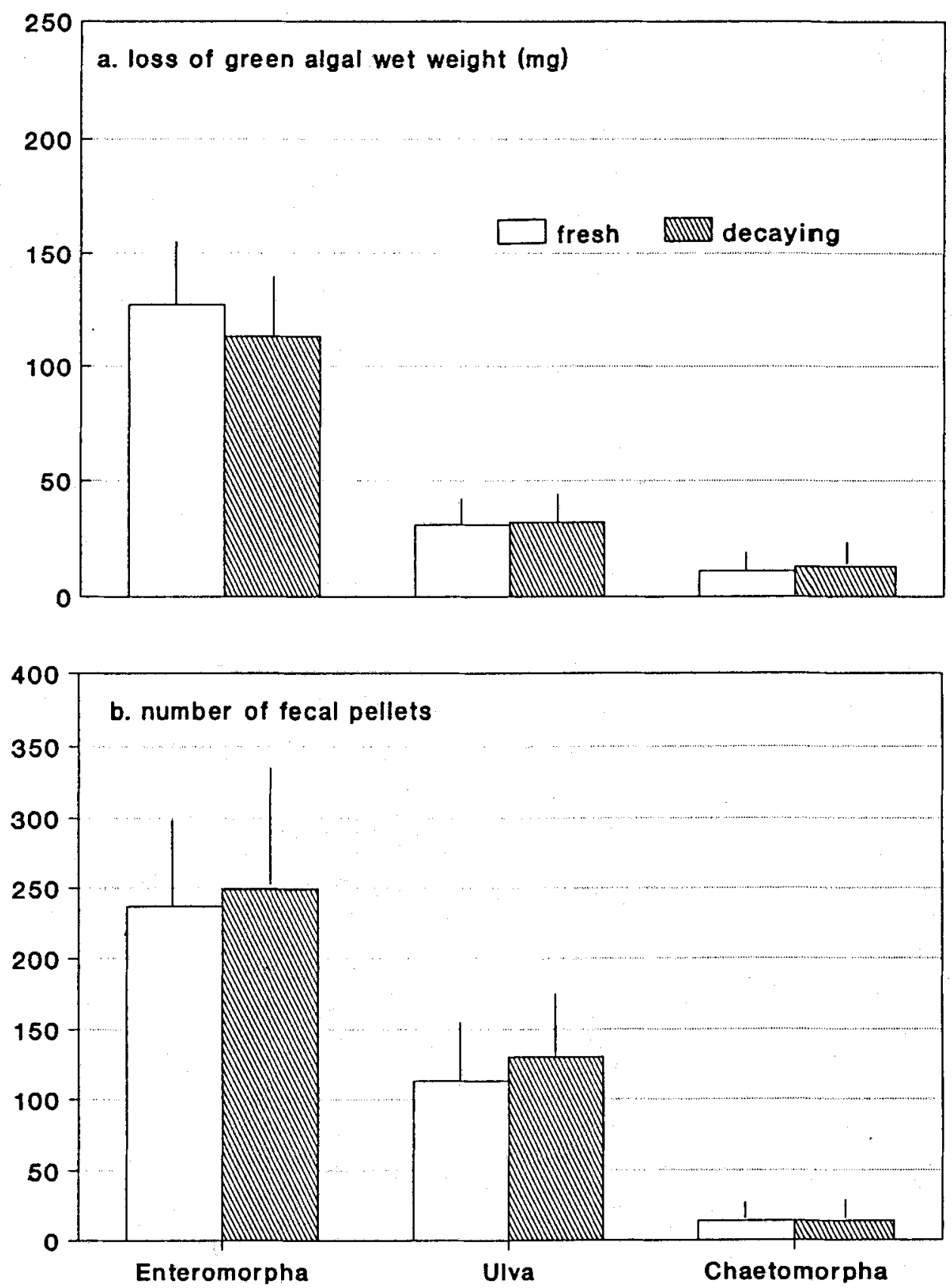

Fig. 2. Ingestion of green algae by Littorina littorea measured as (a) loss of green algal wet weight, and (b) number of fecal pellets produced within one day (means and standard deviation) 


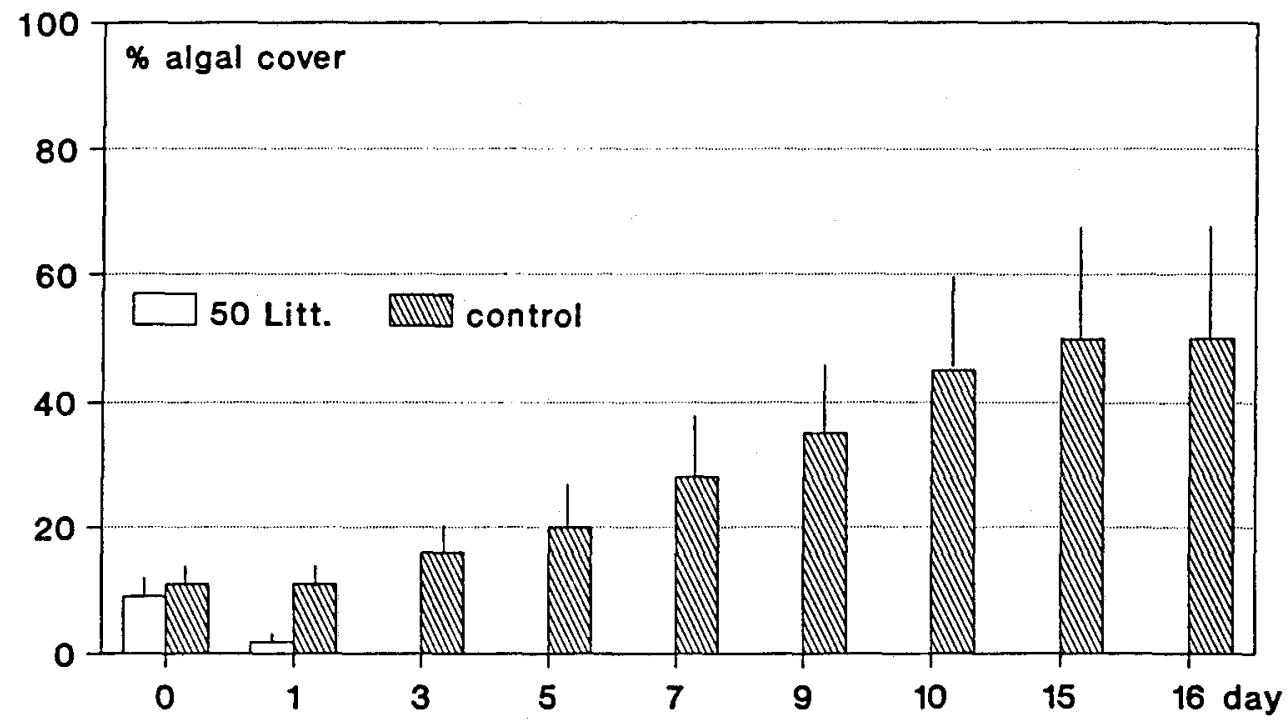

Fig. 3. Effects of Littorina littorea inclusion (50 snails) and exclusion (control) on Enteromorpha coverage within cages $(n=7+7)$ on a sandy flat over a period of 16 days

\section{Exclusion experiments}

Cages $(n=7)$ excluded $240 \pm 32$ snails from clusters of mussels. Natural densities of $244 \pm 48$ remained in the controls $(n=7)$. At the beginning of the experiment, no germlings of green algae were detected. After 2.5 months young thalli of green algae, mainly Enteromorpha, were attached to mussels and fucoids in the cages without periwinkles. Parts of the brown algae were covered with a dense "lawn" of green algal thalli, several $\mathrm{mm}$ in length. No Enteromorpha developed in the control cages, and none were found to develop on ambient clusters without cages.

\section{Survival of green algae after periwinkle digestion}

Fecal pellets produced in the laboratory feeding experiments contained a large amount of undigested algal tissue. Similarly, individuals collected from green algal mats produced fecal pellets with visible pieces of green algal tissue. Pellets from snails collected on bare sediment flats showed no distinct food remains. After a 3-week incubation period, germlings of Enteromorpha occurred in fecal pellets that were produced by snails fed with Enteromorpa in the laboratory experiment as well as by snails feeding in green algal mats. Pellets from snails feeding on bare sediment flats did not develop any germlings. 


\section{DISCUSSION}

\section{Distribution and abundance}

Littorina littorea is able to colonize a variety of hard and soft bottom habitats (Bertness, 1984). On muddy or sandy flats, the population is highly patchy in distribution because sustained development requires a firm substrate, i. e. stones, shells or macroalgae (Bandel, 1974). These structures are of marginal or insular occurrence in the Wadden Sea tidal zone and so is the distributional pattern of $L$. littorea.

\section{Habitat and food quality}

Although Enteromorpha and UIva are shown to be high quality food, Littorina littorea clearly prefers firm substrates to mats of green algae. As slow moving herbivores, periwinkles require macroalgae to serve both as food as well as habitat structure (Watson \& Norton, 1985b). Green algal mats floating with the tides may provide a rather unstable habitat. Therefore, snails prefer the more stable mussel or shell beds. Here they find microscopic food like diatoms or germlings of macroalgae.

Under laboratory conditions, ingestion of different green algae was tested. Littorina littorea preferred the soft thalli of Enteromorpha and Ulva and hardly ingested the tough and rigid Chaetomorpha thalli. The toughness of the thallus surface as a barrier against grazing is an important factor for the edibility of algae (Norton \& Manley, 1990). Periwinkles consumed fragmented pieces of Enteromorpha nearly three times more than those of Ulva. This is because the tissue of Enteromorpha is significantly softer and contains aqueous extracts with strong phagostimulant properties (Watson \& Norton, 1985b). However, littorinids fed with whole algal thalli ingested Ulva twice as much as Enteromorpha (Watson \& Norton, 1985a). This indicates the importance of thallus form: while the broad ulvoid thallus is easily pinned down by the snail's foot to provide a relatively stable food substratum, a single tubular frond of Enteromorpha is too narrow to carry the entire foot and, if inflated with gas, has a strong inherent buoyancy.

\section{Effects of grazing}

On sedimentary flats without any firm substrates (shell gravel, mussel beds), Littorina littorea is incapable of grazing down Enteromorpha because its abundance is too low. According to the literature, this was already the case prior to the advent of the green algal masses in the 1980s (Linke, 1939; Wohlenberg, 1937). Thus, the recent spread of green algae in the Wadden Sea is probably not caused by a release from grazing pressure. Furthermore, the survival of Enteromorpha in fecal pellets suggests that $L$. littorea would not be able to exclude these algae from the tidal zone. With increasing biomass of green macroalgae, the effects of littorinid grazing decreases because incomplete digestion is a consequence of an excess of food (Abele-Oeschger \& Theede, 1991). Tissues of opportunistic green algae have a great totipotency (Santelices \& Ugarte, 1987). Therefore, they are able to regenerate new thalli from undigested algal remains.

It remains an open question whether mussel and shell beds would be covered by green algal mats in the absence of Littorina littorea. This may be inferred from their high 
abundance in these habitats and from the exclusion experiments which indicate that germlings of green algae could establish on shells, mussels and fucoids in the absence of grazing periwinkles. The effects of littorinid grazing on a shell bed was tested by means of an exclusion experiment in two aquaria, both filled with empty shells and sterile seawater. Ten snails were put in one aquarium. This is in accordance to natural densities in shell beds $\left(250 \mathrm{~m}^{-2}\right)$. After one month of incubation in the absence of Littorina littorea, several $\mathrm{mm}$ long green algal thalli occurred on mollusc shells. No green algae were observed in the aquarium containing periwinkles.

Although grazing on microalgae has been generally presumed to be unselective, the periwinkles clearly prefer germlings of Ulva and Enteromorpha to juvenile plantlets of other algae (Watson \& Norton, 1985a). However, the Enteromorpha thalli remained small during the 2.5 months of experimental period. Presumably there may be other inhibiting factors involved. Further experiments are required.

\section{CONCLUSIONS}

Although Enteromorpha is a preferred food of Littorina littorea, effects of grazing on sedimentary flats are small compared to those documented from rocky shores. The underlying cause is the unsuitability of Enteromorpha as a habitat when growing on sediments. In the Wadden Sea tidal zone, L. littorea is not, and probably never was, a grazer controlling green algal growth. A possible exception is the lack of green algae on most mussel beds.

Acknowledgements. We thank A. Albrecht and D. Schories for stimulating discussions on plantanimal interactions in Königshafen. The study was supported by the Federal Environmental Agency; Environmental Natural Research Plan of the Minister for the Environment, Nature Conservation and Nuclear Safety of the Federal Republic of Germany (grant 10802085/01) and the state of SchleswigHolstein. This is publication no. 127 of the project "Ecosystem Research Wadden Sea".

\section{LITERATURE CITED}

Abele-Oeschger, D. \& Theede, H., 1991. Digestion of algal pigments by the common periwinkle Littorina Iittorea L. (Gastropoda). - J. exp. mar. Biol. Ecol. 147, 177-184.

Austen, I, 1990. Geologisch-sedimentologische Kartierung des Königshafens (List auf Sylt) und Untersuchung seiner Sedimente. Dipl.-Arb., Univ. Kiel, 99 pp.

Bandel, K., 1974. Studies on Littorinidae from the Atlantic. - Veliger 17 (2), 92-114.

Bertness, M. D., 1984. Habitat and community modification by an introduced herbivorous snail. Ecology 65 (2), 370-381.

Brenner, D., Valiela, I. \& Raalte, C. D. van, 1976. Grazing by Talorchestia longicornis on an algal mat in a New England salt marsh. - J. exp. mar. Biol. Ecol. 22, 161-169.

Cates, R. G. \& Orians, G. H., 1975. Successional status and the palatability of plants to generalized herbivores. - Ecology 56, 410-418.

Hull, S. C., 1987. Macroalgal mats and species abundance: a field experiment. - Estuar. coast. Shelf Sci. $25,519-532$.

Hylleberg, J. \& Henriksen, K., 1980. The central role of bioturbation in sediment mineralization and element re-cycling. - Ophelia (Suppl.) 1, 1-16.

Jensen, K. T. \& Siegismund, H. R., 1980. The importance of diatoms and bacteria in the diet of Hydrobia-species. - Ophelia (Suppl.) 1, 193-199.

Kornmann, P., 1952. Die Algenvegetation von List auf Sylt. - Helgoländer wiss. Meeresunters. 4, $55-61$. 
Lein, T. E., 1980. The effects of Littorina littorea L. (Gastropoda) grazing on littoral green algae in the inner Oslo-Fjord, Norway. - Sarsia 65, 87-92.

Levinton, J. S. \& McCartney, M., 1991. Use of photosynthetic pigments in sediments as a tracer for sources and fates of macrophyte organic matter. - Mar. Ecol. Prog. Ser. 78, 87-96.

Linke, O., 1939. Die Biota des Jadebusens. - Helgoländer wiss. Meeresunters. 1, 201-348.

Littler, M. M. \& Littler, D. S., 1980. The evolution of thallus form and survival strategies in benthic marine macroalgae: field and laboratory tests of a functional form model. - Am. Nat. 116, 25-44.

Lubchenco, J., 1978. Plant species diversity in a marine intertidal community: importance of herbivore food preference and algal competitive abilities. - Am. Nat. 112, 23-39.

Lubchenco, J., 1983. Littorina and Fucus: effects of hervibores, substratum heterogeneity, and plant escapes during succession. - Ecology 64, 1116-1123.

Meese, R. J. \& Tomich, P. A., 1992. Dots on the rocks: a comparison of percent cover estimation methods. - J. exp. mar. Biol. Ecol. 165, 59-73.

Nicholls, D. J., Tubbs, C. R. \& Haynes, F. N., 1981. The effect of green algal mats on intertidal macrobenthic communities and their predators. - Kieler Meeresforsch. (Sonderh.) 5, 511-520.

Nicotri, M. E., 1980. Factors involved in herbivore food preference. - J. exp. mar. Biol. Ecol. 42, 13-26.

Nienburg, W., 1927. Zur Ökologie der Flora des Wattenmeers. 1. Der Königshafen bei List auf Sylt. Wiss. Meeresunters. (Kiel) 20, 146-196.

Norton, T. A. \& Manley, N. L., 1990. The characteristics of algae in relation to their vulnerability to grazing snails. In: Behavioural mechanisms of food selection. Ed. by R. N. Hughes. Springer, Berlin, 462-478.

Norton, T. A., Hawkins, S. J., Manley, N. L., Williams, G. A. \& Watson, D. C., 1990. Scraping a living: a review of littorinid grazing. - Hydrobiologia 193, 117-138.

Petraitis, P. S., 1983. Grazing patterns of the periwinkle and their effect on sessile intertidal organisms. - Ecology 64, 522-533.

Price, L. H. \& Hylleberg, J., 1982. Algal-faunal interactions in a mat of Ulva fenestra in False Bay, Washington. - Ophelia 21, 75-88.

Reise, K., 1983. Sewage, green algal mats anchored by lugworms, and the effects on Turbellaria and small Polychaeta. - Helgoländer Meeresunters. 36, 151-162.

Reise, K. \& Siebert, I., 1994. Mass occurrence of green algae in the German Wadden Sea. - Dt. hydrogr. Z. (Suppl.) 1, 171-180.

Reise, K., Herre, E. \& Sturm, M., 1989. Historical changes in the benthos of the Wadden Sea around the island of Sylt in the North Sea. - Helgoländer Meeresunters. 43, 417-433.

Santelices, B. \& Ugarte, R., 1987. Algal life-history strategies and resistance to digestion. - Mar. Ecol. Prog. Ser. 35, 267-275.

Shacklock, P. F. \& Doyle, R. W., 1983. Control of epiphytes in seaweed cultures using grazers. Aquaculture 31, 141-151.

Soulsby, P. G., Lowthion, D. \& Houston, M., 1982. Effects of macroalgal mats on the ecology of intertidal mudflats. - Mar. Pollut. Bull. 13 (5), 162-166.

Warwick, R. M., Davey, J. T., Gee, J. M. \& George, C. L., 1982. Faunistic control of Enteromorpha blooms: a field experiment. - J. exp. mar. Biol. Ecol. 56, 23-31.

Watson, D. C. \& Norton, T. A., 1985a. Dietary preferences of the common periwinkle Littorina littorea (L.). - J. exp. mar. Biol. Ecol. 88, 193-211.

Watson, D. C. \& Norton, T. A., 1985b. The physical characteristics of seaweed thalli as deterrents to littorine grazers. - Botanica mar. 28, 383-387.

Wohlenberg, E., 1937. Die Wattenmeer-Lebensgemeinschaft im Königshafen von Sylt. - Helgoländer wiss. Meeresunters. 1, 1-92.

Woodin, S. A., 1977. Algal "gardening" behaviour by nereid polychaetes: effects on soft-bottom community structure. - Mar. Biol. 44, 39-42. 